\title{
Idrætshistoriske tidsskrifter
}

\author{
af Hans Bonde
}

JOURNAL OF SPORT HISTORY, udg.: The North American Society for Sport History, Washington, Seattle.

STADION, Internationale Zeitschrift für Geschichte des Sports und der Körperkultur, Verlag Hans Richarz, Sankt Augustin.

THE BRITISH JOURNAL OF SPORTS HISTORY, Frank Cass \& Co. Ltd., London.

IDROTT HISTORIA OCH SAMHÄLLE, udg.: Svenska Idrottshistoriska Förening, Helsingborg.

I det følgende vil jeg se nærmere på en række af de idrætshistoriske tidsskrifter, som efter min opfattelse er de mest anvendte i Danmark. Tidshorisonten er de sidste 5 års tidsskriftvirksomhed, hvilket bl.a. skyldes, at der i løbet af disse år er skudt en lang række idrætshistoriske tidsskrifter op. Efter denne paddehatteagtige fremvækst at dømme er idrætshistorien nu ved at indtage sin plads ved siden af områder som litteratur- og religionshistorie m.v. Størstedelen af de her anmeldte tidsskriftsnumre kan findes på Danmarks højskole for Legemsøvelsers bibliotek i København og på ,Idrætsforsk"s bibliotek på Gerlev Idrætshøjskole i Slagelse.

JOURNAL OF SPORTHISTORY er et nordamerikansk tidsskrift som debuterede i 1974. Det er relativt populærvidenskabeligt anlagt og udkommer 3 gange om året. Størstedelen af stoffet handler ikke overraskende om sportens historie i USA, men man vil også kunne finde en del artikler om canadisk og især britisk sportshistorie. Tidsskriftet indledes i reglen med 3 store artikler efterfulgt af en meget værdifuld oversigt over indholdet i de enkelte artikler fra nordamerikanske og britiske sportstidsskrifter. Til sidst anmeldes de nyeste bøger. 
Af specielle kendetegn for dette tidsskrift kan nævnes et vedvarende engagement i sportens raceproblematik og i rodeohistorie. Tidsskriftet bygger på et relativt bredt idrætsbegreb, dog ikke så meget $\mathrm{i}$ artiklerne som $\mathrm{i}$ anmeldelserne, hvor dansens historie tages op, og hvor idrætten analyseres $\mathrm{i}$ relation til emner som filosofi, kunst og litteratur.

Tidsskriftet bygger i høj grad på temanumre, som udgør en relativt bred vifte af emner i tid og rum. Bind $10 \mathrm{nr}$. 1 fra 1983 er en guldgrube for folk, der vil orientere sig $\mathrm{i}$ de forskellige landes idrætshistoriske forskningsudvikling, især hvad angår de sidste 10 år. I dette temanummer forsøges der at gøre idrætshistorisk status inden for den antikke, den europæiske, (men desværre ikke den nordiske), den britiske, den canadiske og den nordamerikanske forskning. I forordet konkluderes det, at der de sidste 10-15 år er sket en kraftig udvikling væk fra en traditionelt deskriptiv metode med udgangspunkt $\mathrm{i}$ enkeltstående begivenheder henimod en større tværvidenskabelig tilknytning til f.eks. sociologi, antropologi og statsvidenskab. Der er dog stadig kun tale om en svag forskningsindsats inden for områder som køn, klasser og stat i relation til sportshistorien.

Bind $11 \mathrm{nr} .2$ har temaet ,Ancient Athletics and Ancient Society “, og i 1986 er der planlagt et temanummer om latinamerikansk sport.

STADION er et vesttysk tidsskrift, som første gang så dagens lys i 1975. Tidsskriftet består $i$ reglen af nogle relativt lange og meget grundige artikler efterfulgt af anmeldelser. Artiklerne er tilsyneladende udvalgt efter meget strenge krav om videnskabelig originalitet, og de er langt fra lette at gå til. Der kræves ofte et betydeligt forhåndskendskab til det specifikke emnes bredere historiske miljø. Tidsskriftet har den største bredde såvel indholdsmæssigt som kronologisk og geografisk af de her anmeldte tidsskrifter. I de seneste udgivelser er der dog sket en vis indsnævring $i$ retning af forskning $i$ den antikke kropskultur. Generelt er det denne forskning samt forskning i tysk idrætshistorie før og efter nazisternes magtovertagelse, der optager mest plads.

Blandt temanumrene skal fremhæves ét om moderne og antik olympisk sport fra 1980 (bd. 6), og ét om den tyske gymnastikpionér Jahn (bd. 4, 1978). Glimtvis spores der også en befriende åbenhed over for mere utraditionelle problemstillinger, som f.eks. i bind 7 fra 1981 (s. 131-151), hvor Wolfgang Rothe undersøger flere tyske intellektuelles (bl.a. Brechts) opfattelse af den kolossalt ekspanderende sport i 1920'rnes Tyskland. Eller i bind 8/9, hvor der er en meget spændende billedartikel af Kurt Grasshoff, som omhandler 
„Sport i den impressionistiske maler Max Liebermanns værk (1847-1935)“ (1982/83 s. 105-136.)

Til sidst et surt opstød. Der tales konstant i tidsskriftet om den antikke sport, etruskernes sport o.s.v. Men det er jo langt fra selvfølgeligt, at antikkens kropskultur kan karakteriseres som sport i moderne forstand. Meget tyder tværtimod på, at forskellene er mindst lige så store som lighederne; som eksempel kan nævnes rekordfænomenet $i$ den moderne sport. Kun uhyre sjældent bliver der imidlertid gjort forsøg på at sammenligne de antikke og de moderne olympiske lege, alt for ofte fortaber analysen sig i fragmenterede og detaljerede analyser af enkeltstående fund og begivenheder.

THE BRITISH JOURNAL OF SPORTSHISTORY er et helt nyt tidsskrift; det udkom for første gang i 1984, hvilket er overraskende sent, al den stund Storbritannien er den moderne sports fødested. Tidsskriftet er vokset ud af "History Workshop", som er en bevægelse, hvor lokalbefolkning og akademikere arbejder sammen om socialhistorisk forskning. Tidsskriftet udkommer 3 gange om året, og langt de fleste numre har haft et ledende tema, hvilket har givet bladet en meget helstøbt karakter. Samtidig er den vidtstrakte brug af temanumre et bevis på den engelske idrætsforsknings blomstring $i$ øjeblikket.

Tidsskriftet satser først og fremmest på britisk sportshistorie, men det gør jo ikke noget, når kvaliteten er så høj som den er. F.eks. rummer det første nummer flere helt centrale historiografiske artikler om den britiske sportshistoriske og -sociologiske forskningsudvikling (bd. 1, 1984), bind 2 fra 1984 fremviser et imponerende galleri af artikler om forholdet mellem religion og sport i britisk historie. Endnu et temanummer skal her fremhæves, nemlig det første bind fra 1985, som rummer en lang række artikler om køn i relation til idrætshistorien. At tidsskriftet ikke er bange for at tage utraditionelle problemstillinger op bevidnes af en artikel om cricket, karneval og gadekultur $i$ Caribien i det sidste nummer (nr. 2, 1985, s. 179-198). Alt i alt ser det meget lovende ud, de kommende numre må imødeses med spænding.

IDROTT HISTORIA OCH SAMHÄLLE er titlen på svensk idrætshistorisk forenings årsskrift. Denne forening var den første af sin art i Norden. Den blev stiftet i 1976, og i 1981 kom det første årsskrift. Tidsskriftet består i reglen af en afdeling med en 5-6 artikler efterfulgt af en sektion med omtaler af kongresser m.v. og rapporter om kildematerialeforhold. Der sluttes af med et væld af grundige anmeldelser, ja i reglen er denne sektion lige så stor som artikelsektionen. Artiklerne er $\mathrm{i}$ reglen meget letlæste hvilket dog også hænger sammen med det relativt lave teoretiske ambitionsniveau. Tidsskrif- 
tet er selvfølgelig først og fremmest orienteret mod svensk idrætshistorie, men af og til og ikke mindst $i$ anmeldelserne er der tale om en bredere geografisk orientering.

Artiklerne forekommer lidt spredt mellem hinanden, men det er en stor hjælp, at de alle afsluttes med et referat på engelsk. Det ville dog afgjort give tidsskriftet et større helhedspræg, hvis det ind imellem var muligt at lave temanumre. Blandt artikler af mere generel interesse kan fremhæves Jan Lindroths og Lars Gunnarssons interessante diskussionsoplæg om idrætsideologi (1984 s. 55-79) samt Mats Hellsprongs artikel om idræt og (svensk) etnologi (1981 s. 23-49).

DANSKE TIDSSKRIFTER. Herhjemme fik vi som bekendt først et egentlig idrætshistorisk tidsskrift så sent som i 1985. Og dog, sent og sent, Norge har endnu sit første skrift til gode. Også det sportskritiske tidsskrift Centring, som udgives af forlaget Bavnebanke i Gerlev/Slagelse rummer artikler af sportshistorisk karakter. I samme åndedrag skal nævnes tidsskriftet Den Jyske Historiker, som i 1981 udgav et temanummer kaldet ",sportshistorie“" (Århus, nr. 19/20). Blandt artiklerne her skal blot fremhæves Niels Kayser Nielsens meget inspirerende og tværfaglige introduktion til sportens historiografi.

Ved en sammenligning mellem de udenlandske og de danske tidsskrifter er der umiddelbart ét aspekt, som springer i øjnene: Den svenske gymnastiks stærke placering i Danmark før og efter århundredeskiftet gør det umiddelbart indlysende, at der findes mange andre normer for bevægelsesadfærd end sportens. Dette giver en rigdom i kropskulturbegrebet, som i de udenlandske tidsskrifter alt for ofte indsnævres til i realiteten at være identisk med sportsbegrebet. 
NOGLE RADD TIL DEN DANSKE IDRAETSHISTORISKE ARBOG

Hvis jeg ud fra denne anmeldelse skal trække et par konklusioner op, som kan være relevante for de danske årbøgers videre forløb, vil jeg fremhæve følgende:

1) Bryd de snævre faglige rammer, vær åben over for andre fag.

2) Lav temanumre så ofte som muligt, gerne med en sektion bygget op omkring temaet og en anden, der er mere løst opbygget.

3) Lov ikke mere end ét nummer om året. Det giver et frygteligt tidspres.

4) Bevar de flotte illustrationer og layout.

5) Fasthold og forstærk den enkle og bredt appellerende sprogtone.

6) Byg på et udvidet kropskulturbegreb. Kropskultur er ikke bare sport og gymnastik, men også leg, dans, spejdervæsen, body building, tyrefægtning, ballonfærd, yoga og meget meget mere. 